\title{
ANALISIS KEPUASAN DAN LOYALITAS KONSUMEN KOPI AAA DI KABUPATEN KERINCI
}

\author{
Jahyu Pradinata \\ Sekolah Tinggi Ekonomi Islam Tazkia \\ Jahyupradinata@gmail.com
}

Abstract

\begin{abstract}
Research objectives are to analyze the level of satisfaction of consumers against products of coffee powder Nefo Cap AAA. for consumer loyalty towards mengetahuitingkat ground coffee products Nefo Cap AAA. A sample of these studies amounted to 131 consumers Coffee Nefo Cap Regency AAA Kerinci. The data from this study are obtained from the results of a questionnaire distributed to respondents. This research was analyzed using the methods of Customer Satisfaction Index (CSI), the Importance of Performance Analisys (IPA). The results of this study found that the image of the pyramid Coffee loyalty Nefo Cap $A A A$ in General can be said already quite well. On the level Switcher/Price Buyer has a considerable percentage of the amount that is 57 percent. This can lead to a reduced number of sales in the future due to the consumer at this level are likely to be moved on the ground coffee brand to another if there is a manufacturer that sells ground coffee that is cheaper with the same quality with the brand of coffee Nefo Cap AAA. At the level of the respondent which is brand loyalitas Switcher of $57 \%$, respondents who Hobitual of 69\%, of respondents which is a Satisfied Buyer of 70\%, of the respondents which is Liking the Brand of 68\%, and respondent who is a Committed Buyer of $68 \%$.
\end{abstract}

Keywords: Satisfaction, Loyalty, Customer Satisfaction Index, Importance Performance Analisys

\section{Pendahuluan}

Di Indonesia, kopi menjadi komoditas perkebunan yang sangat digemari oleh penduduk. Hal tersebut dapat dilihat dari peningkatan konsumsi kopi di Indonesia secara keseluruhan. Berdasarkan informasi yang didapat dari ICO Coffee Statistics dan Asosiasi Eksportir Kopi Indonesia (AEKI) pada tahun 2009, secara keseluruhan, konsumsi kopi di dalam negeri mengalami peningkatan yang signifikan. Sebagian besar kopi yang dikonsumsi oleh masyarakat adalah kopi yang telah diolah dan siap untuk dikonsumsi. Kopi olahan dapat berupa kopi dalam kemasan, kopi dalam gelas plastik, dan produk olahan kopi lainnya. 
Perubahan gaya hidup masyarakat yang cenderung konsumtif dan menyenangi produk instan mengakibatkan bertambahnya jumlah pengusaha yang menciptakan produk instan atau praktis guna memenuhi keinginan konsumen. Meningkatnya konsumsi kopi dan perubahan gaya hidup masyarakat menyebabkan mulai berkembangnya industri kopi di Indonesia. Perkembangan produk kopi pada saat ini dapat terlihat dengan banyaknya produk kopi bubuk yang beredar di indoesia karena masyarakat banyak yang suka mengkonsumsi kopi.

Data wawancara prapenelitian dengan pak Hidayat selaku pemilik CV. Nefo kopi murni AAA, perusahaan kopi bubuk Nefo cap AAA merupakan salah satu perusahaan yang bergerak di bidang pengolahan kopi bubuk.Perusahaan ini mengolah biji kopi yang telah di keringkan menjadi bubuk kopi yang siap untuk di konsumsi yang memiliki tekstur dan berwarna hitam pekat, rasanya lebih pahit dan aroma harum alami dan wangi kopi yang baru ditumbuk. Pendistribusian kopi bubuk Nefo cap AAA didistribusikan melalui distributor.

Selain itu dari hasil data wawancara prapenelitian bersama bapak Hidayat juga di jelaskan bahwa kopi Nefo cap AAA yang di produksi di kota Jambi berkembang sejak tahun 1965 hingga sekarang dengan mengalami fase persaingan yang sangat ketat dengan produk kopi yang ada di Provinsi Jambi sendiri seperti kopi Nur dan kopi Blue Korintji yang ada di Kabupaten Kerinci. Dalam hal ini pesaing kopi Nefo cap AAA yaitu kopi Blue Korintji yang telah mendapatkan sertifikat Asosiasi Eksportir dan Industri Kopi Indonesia (AEKI) pada tahun 2015 (www.korintji.com)

Masuknya beberapa pemain baru dalam industri kopi bubuk sebagai dampak besarnya peluang pertumbuhan terhadap permintaan mennyebabkan persaingan semakin ketat. Persaingan ini tentu akan mempengaruhi penjualan perusahaan kopi Nefo cap AAA yang telah lama bergerak di industry kopi bubuk, sehingga perlu menjaga loyalitas konsumen dengan cara memaksimalkan kinerja dari atribut-atribut produk mereka.

Sebagai sebuah usaha yang bergerak dibidang pengolahan kopi, produsen kopi bubuk Nefo cap AAA harus mengetahui selera konsumen, sehingga produk ini dapat diterima dengan baik oleh masyarakat dan dapat terus melebarkan sayap. Sebagai usaha pengolahan kopi yang cukup lama di pasaran, produsen kopi bubuk Nefo cap AAA ini perlu mengetahui atribut-atribut apa saja yang dapat menciptakan kepuasan bagi konsumen kopi bubuk Nefo cap AAA sehingga dapat menciptakan loyalitas konsumen terhadap kopi bubuk Nefo cap AAA. Hal tersebut dilakukan untuk menemukan strategi yang tepat agar terus menghadapi pesaing kopi bubuk yang semakin ketat. Maka dari itu, penulis membuat penelitian ini untuk menganalisa tingkat kepuasan dan loyalitas konsumen terhadap brand kopi bubuk Nefo cap AAA. 


\section{Tinjauan Pustaka}

\section{PeneltianTerdahulu}

Berbagai penelitian telah dilakukan untuk menganalisis kepuasan dan loyalitas konsumen di berbagai restoran.Salah satunya adalah penelitian yang dilakukan oleh Kelana (2007) dengan judul "Tingkat Kepuasan dan Loyalitas Pelanggan Restoran Bandar Djakarta di Jakarta Utara". Penelitian dilakukan dengan menggunakan Importance Performance Analisys (IPA), Customer Satisfaction Index (CSI) dan analisis tingkat penyesuaian dan analisis kesenjangan.Importance Performance Analisys digunakan untuk menilai tingkat kepentingan dan tingkat kinerja restoran Bandar Djakarta, Customer Satisfaction Index (CSI) digunakan untuk mengetahui tingkat kepuasan responden secara menyeluruh, analisis tingkat kesesuaian dan analisis kesenjangan digunakan untuk mengetahui apakah suatu atribut sudah memenuhi harapan konsumen atau belum. Secara keseluruhan indeks kepuasan Restoran Bandar Djakarta adalah 68,33 persen yang berarti responden Restoran Bandar Djakarta merasa puas akan kinerja atribut yang mempengaruhi tingkat kepuasan pelanggan. Dalam kategori loyalitas 76 persen termasuk kategori clients, 20 persen repeated costumer, dan 4 persen advocates.

Penelitian lain yang manganalisis kepuasan dan loyalitas konsumen yaitu penelitian yang dilakukan oleh Hendrayani (2008) dengan judul "Analisis Tingkat Kepuasan dan Loyalitas Konsumen Terhadap Produk Gulaku di Kota Bogor (Studi Kasus di Giant Botani Square dan Ramayana BTM)”. Data yang digunakan dalam penelitian ini adalah data sekunder yang berasal dari literatur dan data primer yang berasal dari survei dan observasi baik dari pihak manajemen maupun konsumen responden.Dalam melakukan penelitian ini, penulis menggunakan metode analisis deskriptif, Customer Satisfaction Index (CSI), Importance Performance Analisys (IPA), dan pengukuran loyalitas pelanggan. Analisis deskriptif digunakan untuk mengetahui karakteristik konsumen, Importance Performance Analisys (IPA) digunakan untuk menilai tingkat kepentingan dan tingkat kinerja Restoran Bandar Djakarta, Customer Satisfaction Index (CSI) digunakan untuk mengetahui tingkat kepuasan responden secara menyeluruh. Karakteristik konsumen yang membeli gula pasir merek gulaku adalah perempuan dewasa dengan usia 31 sampai dengan 40 tahun, sudah menikah dengan jumlah keluarga 3 sampai 4 orang, Suku Sunda dengan pekerjaan utama ibu rumah tangga, berpendidikan SMU dan sarjana dengan pendapatan keluarga hampir tersebar merata dari semua kalangan. Tingkat kepuasan konsumen terhadap kinerja yang diberikan oleh produk gulaku yaitu sebesar 77,73 persensehingga berada pada criteria puas, loyalitas konsumen terhadap gula pasir Gulaku belum pada tahap pembeli yang loyal karena pada piramida loyalitas, nilai commited buyer merupakan nilai yang cukup kecil yaitu sebesar 39 persen.

Penelitian lainnya yaitu penelitian yang dilakukan oleh Firadaus (2008) dengan judul "Analisis Kepuasan Konsumen de Excelso Coffee Mall Kelapa Gading 3 Jakarta".Penelitian ini dilakukan di Mall Kelapa Gading 3. Untuk mencapai tujuan penelitian, penulis menggunakan teknik pengolahan tabulasi deskriptif dengan analisis crosstabs yang digunakan untuk menganalisiskarakteristik konsumen de Excelso Coffee dan proses keputusan pembelian, Analisis SEM dan Customer Satisfaction Index (CSI) 
untuk mengukur tingkat kepuasan konsumen terhadap de Excelso Coffee. Berdasarkan hasil penelitian pada 130 responden, karakteristik konsumen de Excelso Coffee adalah berjenis kelamin perempuan, berdomisili di Jakarta, sarjana, pegawai swasta, penghasilan di atas lima juta. Proses keputusan pembelian terlihat dari pengenalan kebutuhan yaitu de Excelso Coffee merupakan tempat yang nyaman dan santai, peran teman sangat menonjol dalam pencarian informasi, de Excelso Coffee dianggap sama dengan coffeeshop lainnya, sebagian besar konsumen merasa puas sehingga merekomendasikan de Excelso Coffee kepada orang lain.

Penelitian ini dilakukan oleh Curtis dkk (2011), dengan judul customer loyalty, repurchase and statisfaction: a meta-analytical review tujuan artikel ini adalah untuk mengetahui hubungan antara loyalitas pelanggan, pembelian kembali / pembelian kembali maksud dan kepuasan dalam rangka upaya untuk mengatasi pandangan campuran pada konsep-konsep ini. Sebuah tinjauan kuantitatif konstruksi kepuasan dan loyalitas pelanggan dilakukan untuk mengidentifikasi kekuatan dan arah hubunngan diteliti dan pengaruh faktor moderating mungkin mempengaruhi hubungan mereka.The Hunter dan Schmidt teknik (1990) meta-analisis dan software yang digunakan. Hasil menunjukkan bahwa loyalitas dan kepuasan menunjukkan hubungan positif yang kuat $(0,54)$. Repurchase dan kepuasan menampilkan hubungan yang rumit, yang menegaskan pandangan bahwa kepuasan tidak menjelaskan perilaku pembelian kembali. Pembelian kembali maksud dan display kepuasan hubungan positifyang kuat dalam meta-analisis $(0,63)$ dan moderator analisis. Loyalitas dan pembelian kembali / pembelian kembali maksud menunjukkan hubungan positif kuat $(0,71)$ di antara semua analisis dilakukan.Studi ini memberikan nilai untuk manajer berurusan dengan kepuasan pelanggan, loyalitas, dan pembelian kembali dengan menghadirkan gambaran rinci dari ketiga konsep ini, dan hubungan di antara mereka.

Peelitian ini dilakukan oleh Awan (2014), dengan judul impact of customer statisfaction on brand loyalty-an empirical analysis of home appliances in pakistankepuasan pelanggan dan loyalitas merek telah ditangani sebagai market tujuan bagi banyak perusahaan. Profesional pemasaran mempertimbangkan loyalitas menjadi fenomena multidimensi. Meskipun temuan banyak penelitian kepuasan yang memiliki dampak yang menguntungkan signifikan terhadap loyalitas merek dan perilaku pembelian ulang dari merek yang sama mengarah ke keuntungan bisnis jangka panjang. Oleh karena itu, penelitian ini meneliti dampak kepuasan pelanggan terhadap loyalitas merek untuk barang- barang tahan lama.Penulis menggunakan data primer dalam penelitian ini dan untuk tujuan ini survey telah dilakukan melalui kuesioner terstruktur. Pandangan 300 rumah tangga kelas menengah atau orang-orang bisnis dicatat. Hasil penelitian kami menunjukkan bahwa kepuasan pelanggan memiliki faktor signifikan yang mempengaruhi loyalitas merek.

\section{MetodePenelitan}

\subsection{Lokasi dan Waktu Penelitian}

Penelitian ini dilakukan di sebuah daerah yang terdapat di Provinsi Jambi, kabupaten Kerinci merupakan daerah yang terletak di Provinsi Jambi merupakan daerah 
tempat penelitian dilakukan.Waktu penelitian dilakukan pada bulan April sampai Juni 2017.

\subsection{Populasi dan Sampel}

Dalam penelitian ini tidak seluruh populasi dijadikan sumber data, tetapi hanya diambil sebbagian dari populasi sebagai populasi untuk memperoleh data .populasi dalam penelitian ini adalah konsumen kopi Nefo cap AAA kabupaten Kerinci Provinsi Jambi. Kategori data konsumen yang diambil adalah konsumen yang sebelumnya pernah melakukan pembelian kopi Nefo cap AAA, sehingga dapat diketahui konsumen telah mengetahui kopi Nefo cap AAA dan pernah mengkonsumsi produk kopi Nefo cap AAA.

Ukuran populasi konsumen kopi Nefo cap AAA tidak diketahui secara pasti. Oleh karena itu, jumlah sampel yang digunakan adalah berdasarkan pendekatan jumlah pengunjung rata-rata per bulan. Jumlah responden yang diambil sebagai sampel ditentukan dengan menggunakan rumus Slovin yaitu:

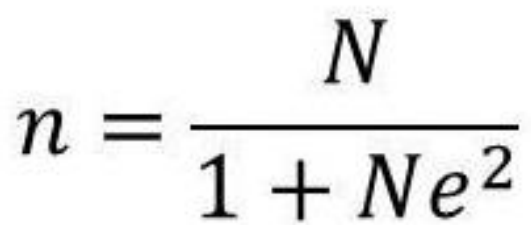

Keterangan:

$\mathrm{n} \quad=$ jumlah responden yangdiambil

$\mathrm{N}=$ jumlah populasi atau rata-ratakonsumen

$\mathrm{E} \quad=$ persen kelonggaran ketidaktelitian karena kesalahan pengambilan responden yang masih dapat ditolerir (pada umumnya digunakan 5\%).

Dalam penelitian ini dapun konsumen Kopi Nefo Cap AAA yang diambil sebagai responden dalam penelitian ini merupakan responden yang pernah mengkonsumsi Kopi Nefo Cap AAA, serta mengkonsumsi Kopi Nefo Cap AAA dalam waktu paling lama enam bulan terakhir pada saat penelitian dilakukan. Dalam hal ini konsumen Kopi Nefo Cap AAA yang ditemui di Kabupaten Kerinci.Untuk mengetahui jumlah responden dalam penelitian ini maka diambil sampel jumlah produksi Kopi Nefo Cap AAA dalam satu tahun maka didapat angka 35.000, didapat angka 99.70 sebagai angka jumlah responden. 


\subsection{Analisis Data}

\section{Uji Validitas danReliabilitas}

Pengujian validitas setiap butir pertanyaan di dalam kuesioner dilakukan dengan menggunakan alat ukur korelasi rank spearman dengan bantuan perangkat lunak SPSS versi 16. Bila diperoleh sig (1-tailed) $\leq \alpha(\alpha=0,05)$, maka pertanyaan tersebut valid (Suliyanto, 2005). Pengujian reabilitas dilakukan dengan menggunakan rumus AlphaCronbach dengan alat bantu perangkat lunak SPSS versi 16. Jika nilai Alpha lebih dari 0,377 nilai $\mathrm{r}$ dari table rank spearman, $\mathrm{df}=(\alpha, \mathrm{n}-2)$, maka pertanyaan tersebutreliabel.

\section{Customer Satisfaction Index (CSI) danImportance Performance Analysis (IPA).}

Customer satisfaction index (CSI), digunakan untuk menentukan tingkat kepuasan pelanggan secara menyeluruh dengan pendekatan yang mempertimbangkan tingkat kepentingan dari variablevariabel yang diukur. Menurut Huan dan Beaman.(2005), Importance Performance Analysis merupakan suatu teknik yang digunakan untuk mengukur kepentingan dan tingkat kinerja atribut yang diformulasikan oleh Martilla. Penilaian tingkat kinerja yang dapat mempengaruhi kepuasan konsumen akan diwakili oleh huruf $X$, sedangkan untuk penilaian tingkat kepentikang diwakili oleh huruf Y. untuk menilai kinerja dan kepentingan konsumen.

\section{Pengukuran Loyalitas Pelanggan}

Menurut Dusrianto,dkk (2004), untuk melakukan analisis tingkat loyalitas konsumen terdapat beberapa analisis seperti switcher buyer, Hobitual buyer,statisfied buyer, linking the brand, committed buyer. Metode analisis Switcher Buyer adalah konsumen yang sensitive terhadap perubahan harga, sehingga pada tinggkat loyalitas ditempatkan pada urutan paling bawah. Responden yang termasukdalam kategori Swicther Buyer adalah responden yang menjawab "setuju" dan "sangat setuju" bahwa mereka melakukan pembelian dengan alasan harga yang lebih kuat dibandingkan dengan alasan yang lain.

\section{Hasil Penelitian DanPembahasan \\ 4.1 Pengujian Validitas dan Reliabel}

Tabel 1: Hasil Uji Validitas

\begin{tabular}{|c|c|c|c|c|}
\hline Variabel & Item Pertanyaan & r table & r hitung & Keterangan \\
\hline \multirow{7}{*}{ Kepentingan } & 1 & 0.176 & 0.410 & Valid \\
\cline { 2 - 5 } & 2 & 0.176 & 0.479 & Valid \\
\cline { 2 - 5 } & 3 & 0.176 & 0.429 & Valid \\
\cline { 2 - 5 } & 4 & 0.176 & 0.467 & Valid \\
\cline { 2 - 5 } & 5 & 0.176 & 0.636 & Valid \\
\cline { 2 - 5 } & 6 & 0.176 & 0.546 & Valid \\
\cline { 2 - 5 } & 7 & 0.176 & 0.447 & Valid \\
\cline { 2 - 5 } & 8 & 0.176 & 0.426 & Valid \\
\cline { 2 - 5 } & 9 & 0.176 & 0.553 & Valid \\
\hline
\end{tabular}


AL-INFAQ: Jurnal Ekonomi Islam, (p-ISSN: 2087-2178, e-ISSN: 2579-6453)

Vol. 8 No. 2, December 2017

\begin{tabular}{|c|c|c|c|c|}
\hline \multirow[t]{4}{*}{ Kepentingan } & Item Pertanyaan & $r$ table & r hitung & Keterangan \\
\hline & 11 & 0.176 & 0.586 & Valid \\
\hline & 12 & 0.176 & 0.420 & Valid \\
\hline & 13 & 0.176 & 0.402 & Valid \\
\hline \multirow{13}{*}{ Kinerja } & 1 & 0.176 & 0.413 & Valid \\
\hline & 2 & 0.176 & 0.294 & Valid \\
\hline & 3 & 0.176 & 0.576 & Valid \\
\hline & 4 & 0.176 & 0.402 & Valid \\
\hline & 5 & 0.176 & 0.519 & Valid \\
\hline & 6 & 0.176 & 0.592 & Valid \\
\hline & 7 & 0.176 & 0.606 & Valid \\
\hline & 8 & 0.176 & 0.534 & Valid \\
\hline & 9 & 0.176 & 0.494 & Valid \\
\hline & 10 & 0.176 & 0.593 & Valid \\
\hline & 11 & 0.176 & 0.529 & Valid \\
\hline & 12 & 0.176 & 0.584 & Valid \\
\hline & 13 & 0.176 & 0.444 & Valid \\
\hline \multirow{5}{*}{ Loyalitas } & 1 & 0.176 & 0.444 & Valid \\
\hline & 2 & 0.176 & 0.479 & Valid \\
\hline & 3 & 0.176 & 0.473 & Valid \\
\hline & 4 & 0.176 & 0.565 & Valid \\
\hline & 5 & 0.176 & 0.568 & Valid \\
\hline
\end{tabular}

Sumber: Data SPSS yang diolah (2017)

Berdasarkan hasil uji validitas menunjukkan bahwa nilai korelasi setiap item peryataan dengan total skor yang lebih besar dari 0,176 sehingga dapat dijelaskan bahwa item pernyataan yang digunakan adalah valid dan dapat digunakan dalam analisis data selanjutnya.

Tabel 2: Hasil Uji Reliabilitas

\begin{tabular}{|l|l|}
\hline $\begin{array}{c}\text { Cronbach's } \\
\text { Alpha }\end{array}$ & N of Items \\
\hline .894 & 31 \\
\hline
\end{tabular}

Sumber data SPSS yang diolah (2017)

Berdasarkan tabel diatas diketahui bahwa nilai dari Cronbach Alpha lebih besar dari 0,6 yaitu 0,894 maka dari itu dapat disimpulkan bahwa angket/kuisioner dalam penelitian ini dinyatakanreliabel. 


\subsection{Pengujian Importance Performance Analysis(Ipa)}

Tabel 3: Perhitungan rata-rata dari Penilaian Tingkat Kepetingan dan Tingkat Kinerja Atribut Kualitas Kopi Nefo Cap AAA.

\begin{tabular}{|l|l|c|c|}
\hline \multirow{2}{*}{ No } & \multicolumn{1}{|c|}{ ATRIBUT PRODUK } & $\begin{array}{c}\text { IMPORTANCE } \\
(\mathbf{Y})\end{array}$ & $\begin{array}{c}\text { PERFORMANCE } \\
(\mathbf{X})\end{array}$ \\
\hline 1 & Merek & 3,81 & 3,55 \\
\hline 2 & Harga kopi & 3,94 & 3,64 \\
\hline 3 & Rasa kopi & 4,27 & 3,82 \\
\hline 4 & Bersih dari benda selain kopi & 4,28 & 3,98 \\
\hline 5 & Ukuran berat bervariasi & 3,71 & 3,89 \\
\hline 6 & Kemudahan memperoleh kopi & 3,94 & 3,82 \\
\hline 7 & Bentuk atau desain kemasan & 3,75 & 3,44 \\
\hline 8 & Jaminan Halal dan sehat & 4,39 & 3,92 \\
\hline 9 & Iklan kopi & 3,86 & 3,31 \\
\hline 10 & Ketersediaan tanggal kadaluarsa pada & 4,50 & 3,95 \\
& produk & 3,95 & 3,78 \\
\hline 11 & Lokasi penjualan kopi & 4,31 & 3,86 \\
\hline 12 & Daya tahan kopi untuk disimpan & 4,34 & 4 \\
\hline 13 & Kemudahan dilarutkan $\quad$ Jumlah & 53,05 & 48,96 \\
\hline \multicolumn{2}{r|}{ Rata-Rata } & 4,08 & 3,77 \\
\hline \multicolumn{2}{r|}{} \\
\hline
\end{tabular}

Dari perhitungan tersebut diperoleh empat kuadran pada diagram kertesius Importance and Performance Analysis dengan garis tengah pembagi adalah ratarata dari skor tingkat kepentingan yang bernilai 4,08 dan rata-rata tingkat kinerja yang bernilai 3,77 sebaran ke 13 variabel dapat dilihat pada tabel 3. Keempat kuadran yang berisi atribut inilah yang akan digunakan untuk mengetahui mana atribut yang sebaiknya dipertahankan maupunditingkatkan.

Setelah mengetahui nilai rata-rata tingkat kepentingan dan kinerja dari masing-masing atribut, maka steiap atribut kualitas produk yang dapat mempengaruhi kepuasan konsumen perlu diperbaki seriring dengan berjalanya waktu.Meskipun demikian, perbaikan kinerja tersebut perlu mempertimbangkan sumber daya yang terbatas, sehingga CV.NEFO harus dapat megalokasikan sumber daya terhadap perbaika kinerja atribut yang mampu memberikan mafaat lebi besar untuk kepuasan konsumen.Hal yang perlu dipertimbangkan oleh pihak perusahaan adalah memproritaskan atribut yang dianggap memiliki tingkat kepentingan yang tinggi oleh konsumen namun memiliki tingkat kinerja yang rendah. Salah satu cara untuk menentukan prioritas perbaikan tehadap kinerja atribut produk Kopi Nefo Cap AAA adalah dengan menggunaka alat bantu berupa analisis kuadran kartesius sperti terlihat pada gambar 1 . 


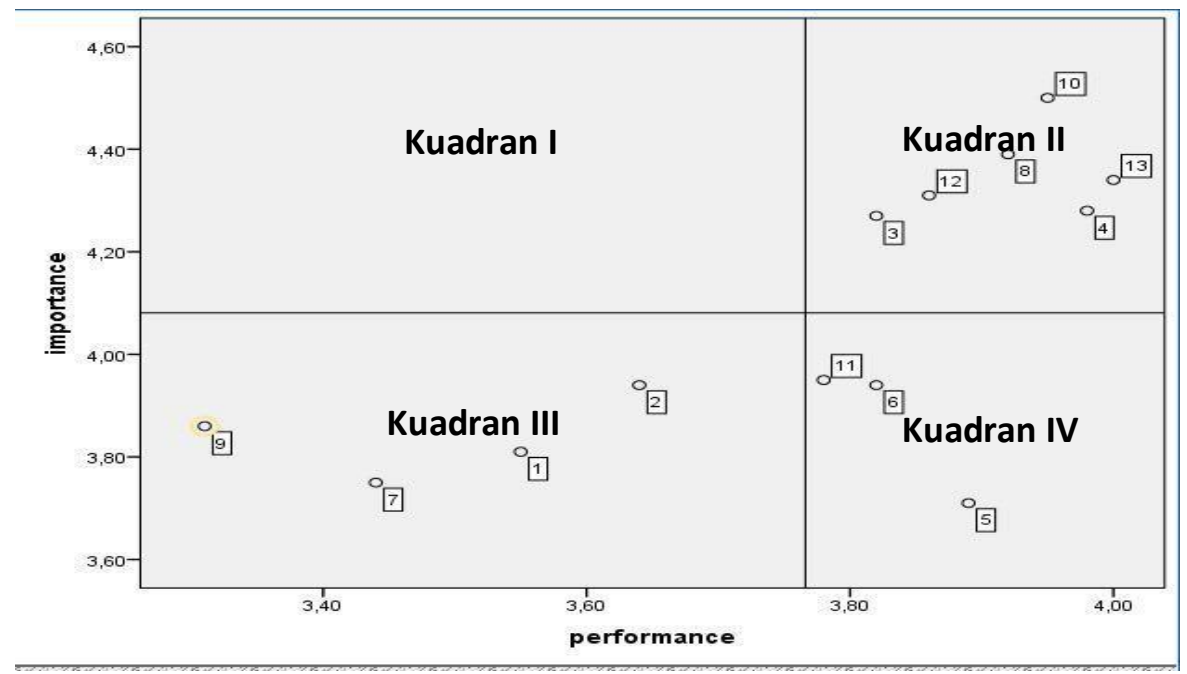

Gambar 1: Posisi Kopi Nefo Cap AAA dalam diagram kartesius

Importance and Performance Analysis (IPA)

Keterangan:

1. Merek

2. Hargakopi

3. Rasakopi

4. Bersih dari benda selain kopi

5. Ukuran beratbervariasi

6. Kemudahan memperoleh kopi

7. Bentuk atau desainkemasan

8. Jaminan halal dansehat

9. Iklankopi

10. Ketersedian tanggalkadaluarsa

11. Lokasipenjualan

12. Daya tahankopi

13. Kemudahandilarutkan

Pada kuadran I atau tidak terdapat variabel.Pada kuadran II atau pertahankan prestasi terdapat enam variabel yaitu rasa, kebersihan dari benda selain kopi, jaminan halal dan sehat, ketersediaan tanggal kadaluarsa pada produk, daya tahan kopi untuk disimpan, kemudahan dilarutkan. Pada kuadran III atau prioritas rendah terdapat empat buah variabel yaitu merek, harga, bentuk atau desaign kemasan, iklan.Pada kuadran IV atau berlebihan terdapat tiga buah variabel yaitu ukuran berat variasi, kemudahan memperoleh, lokasi penjualan.

Pemetaan berdasarkan tingkat kepentingan dan kinerja ini memungkinkan pihak perusahaan CV. NEFO untuk melakukan perbaikan- perbaikan pada atribut yang dianggap pennting oleh konsumen. Setiap kuadran tersebut dapat dijelaskan dengan interprestasi sebagai berikut: 
a. Prioritas Utama (Kuadran I)

Kuadran I diagram kartesius Importance and Performance Anlysis (IPA) berarti tingkat kepentingan dari variabel diangap oleh konsumen sangat penting, tetapi kinerja dari variabel ini dianggap biasa saja dan kurang memuaskan. Dengan demikian, variabel ini harus menjadi prioritas utama bagi perusahaan Kopi Nefo Cap AAA untuk meningkatkan kepuasan konsumen. Tidak ada atribut yang terdapat pada kuadran I.

b. Pertahankan Prestassi (Kuadran II)

Kuadran II menunjukan kinerja atribut yang sudah sesuai dengan harapan konsumen.Atribut-atribut yang termasuk ke dalam kuadran ini adalah atribut rasa, bersih dari benda selain kopi, jaminan halal dan sehat, ketersediaan tanggal pada produk, daya tahan, kemudahan dilarutkan.Pihak CV. NEFO yang sudah memaksimalkan kinerja atribut ini membuat konsumenmerasa puas membeli Kopi Nefo Cap AAA, sehingga perusahaan harus dapat mempertahankan kinerja dari atribut ini.

Salah satu hal yang diperhatikan konsumen dalam membeli Kopi Nefo Cap AAA adalah kemudahan dilarutkan.Kemudahan dilarutkan dinilai dari ada tidaknya ampas pada kopi pada saat di seduh.Kopi Nefo Cap AAA menurut responden kemudahan dilarutkan sudah sangatbaik.

Konsumen juga semakin perhatian terhadap kesehatan dan kebersihan. Kebersihan dinilai dari ada tidaknya benda lain seperti pasir atau kotoran yang bergabung dengan bubuk kopi. Kopi Nefo Cap AAA menurut responden kebersihannya sudah baik.

Ketersediaan tanggal kadaluarsa merupakan atribut yang dinilai penting bagi konsumen Kopi Nefo Cap AAA.Dengan adanya tanggal kadaluarsa membuat konsumen semakin percaya produk yang diterima aman untuk digunakan.Kinerja dari atribut ini dinilai konsumen sudah baik karena Kopi Nefo Cap AAA telah mencantumkan tanggal kadaluarsa pada bagian belakang kemasan dan terlihat jelas oleh konsumen.Hal ini sudah sesuai dengan keinginan konsumen terhadap produk Kopi Nefo Cap AAA.

Salah satu hal yang diperhatikan konsumen dalam membeli Kopi Nefo Cap AAA adalah jaminan halal. Ketersediaan cap halal pada produk Kopi Nefo Cap AAA juga mempengaruhi konsumen dalam pembelian dan juga menjdi salah satu pertimbangan pada saat membeliproduk.

Daya tahan merupakan suatu indikasi suatu produk tahan lama untuk disimpan.Daya tahan merupakan atribut yang dianggap penting oleh konsumen, karena untuk kopi bubuk konsumen terbiasa untuk melakukan penyimpanan selama sebulan atau lebih.Konsumen menilai kinerja Kopi Nefo Cap AAA untuk disimpan kinerjanya baik. 
Salah saatu faktor yang mempengaruhi kesetiaan konsumen terhadap suatu produk adalah rasa. Seorang yang loyal terhadap suatu produk tertentu akan melakukan pembelian ulang terhadap produk tersebut, namun ketika produk tersebut tidak memiliki rasa yang membuat konsumen puas maka kesetiaan tersebut dapat memudar dan beralih ke produk yang lebih dapat memuaskan konsumen. Kinerja dari atribut ini sudah sangat sesuai dengan kebutuhan dan keinginan konsumen sehingga harus terus dipertahankan oleh perusahaan.

c. Prioritas Rendah (Kuadran III)

Kuadran III diagram kartesius Importance and Performance Analysis (IPA) dianggap kurang penting oleh konsumen Kopi Nefo Cap AAA dan pada kenyataannya kinerjanya tidak terlalu istimewa. Dengan demikian variabel ini harus diperbaiki kinerjanya serta pihak perusahaan CV.Nefo memperbaiki kinerja variabel yang terdapat pada kuadran I (prioritas utama).Variabel yang termasuk dalam kuadran ini berjumlah empat macam yaitu merek, harga, bentuk atau desaign kemasan, iklankopi.

Merk merupakan nama, istilah, tanda, simbol desin ataupun kombinasinya yang mengidentifikasikan suatu produk atau jasa yang dihasilkan oleh suatu perusahaan. Merek Kopi Nefo cap AAA adalah merek yang digunakan CV. Nefo untuk produk kopi bubuk yang dihasilkannya. Konsumen merasakan atribut merek pada Kopi Nefo cap AAA kuarang penting. Konsumen menganggap Kopi Nefo Cap AAA ini sama dengan kopi bubuk lainnya.

Konsumen merasa tingkat kepentingan untuk harga tidak terlalu penting. Hal ini karena konsumen Kopi Nefo Cap AAA terbiasa membeli dengan harga yang konsisten dan sangat terjangkau bagi konsumen. Jadi untuk atribut harga saat ini tidak harus diprioritaskan oleh $\mathrm{CV}$. Nefo karena menurut konsumen Kopi Nefo Cap AAA tidak terlalu penting.

Desain kemasan hampir sama dengan merek, desain kemasan Kopi Nefo Cap AAA dianggap kurang penting bagi konsumen karena konsumen beranggapan bahwa desain kemsan merupakan atribut yang tidak menjadi dasar dalam pembelian Kopi Nefo Cap AAA.

Iklan kopi adalah sarana promosi perusahaan kopi bubuk untuk mempromosikan diri baik melalui elektronik maupun surat kabar. Bagi konsumen ada atau tidaknya iklan tidak terlalu masalah. Jadi walaupun konsumen iklan tidak ada konsumen akan tetap membeli Koi Nefo Cap AAA.

d. Berlebihan (Kuadran IV)

Kuadran IV diagram kartesius Importance and Performance Analysis (IPA) berarti tingkat kepentingan dari suatu variabel dianggap oleh konsumen 
rendah, tetapi kinerja dari variabel ini dianggap tinggi oleh konsumen Kopi Nefo Cap AAA. Atribut tersebut yaitu ukuran berat bervariasi, kemudahan memperoleh, lokasi penjualan. Pada saat ini pihak perusahaan CV. Nefo perlu meningkatkan kinerja dari ketiga atribut ini, karena peningkatan terhadap atribut ini kan ddianggap berlebihan oleh konsumen.

Ukuran berat bervariasi adalah variasi ukuran berat Kopi bubuk merek Nefo Cap AAA yang dijual kepada konsuemen.Konsumen merassa tingkat kepentingan dari atribut ini berlebihan. Kinerja dari atribut ini dinilai oleh konsumen sudah sangat baik untuk Kopi Nefo Cap AAA namun konsumen menganggap ukuran Kopi Nefo cap AAA sama pada kopi bubuk biasanya.

Salah satu faktor yang mempengaruhi kesetiaan konsumen terhadap suatu produk adalah kemudahan dalam memperoleh produk.Menurut konsumen Kopi Nefo Cap AAA, kemudahan memperoleh merupakan atribut yang berlebihan karena konsumen menganggap atribut ini tidaakpenting.

Lokasi penjualan merupakan tempat dimana Kopi Nefo dijual.Saat ini Kopi Nefo Cap AAA banyak dijual di warung-warung kecil selain dari supermarket dan mini market.Konsumen Kopi Nefo Cap AAA untuk atribut lokai penjualan dianggap oleh konsumen berlebihan.

\subsection{Pengujian Customer Satisfaction Index (CSI)}

Hasil perhitungan indeks kepuasan keseluruhan konsumen yang mampu dihasilkan oleh produk Kopi Nefo Cap AAA pada tabel 4.15.

Tabel 4: Perhitungan CSI

\begin{tabular}{|l|c|l|c|c|}
\hline \multicolumn{5}{|c|}{ TABEL PERHITUNGAN CSI } \\
\hline Atribut & $\begin{array}{c}\text { RATA-RATA } \\
\text { SKOR } \\
\text { KEPENTING } \\
\text { AN }(\mathbf{R S P})\end{array}$ & $\begin{array}{c}\text { WEIGHTIN } \\
\text { G FACTOR } \\
\text { [WF=(RSP/ } \\
\mathbf{5 3 , 0 5})]\end{array}$ & $\begin{array}{c}\text { RATA-RATA } \\
\text { SKOR } \\
\text { KEPUASAN } \\
\text { (RSK) }\end{array}$ & $\begin{array}{c}\text { WEIGHTED } \\
\text { SCORE } \\
\text { [WS=(RSK } \\
\text { X WF)] }\end{array}$ \\
\hline Merek & 3,81 & 0,0718 & 3,55 & 0,254 \\
\hline Harga kopi & 3,94 & 0,0742 & 3,64 & 0,270 \\
\hline Rasa kopi & 4,27 & 0,0804 & 3,82 & 0,307 \\
\hline $\begin{array}{l}\text { Bersih daribenda } \\
\text { selain kopi }\end{array}$ & 4,28 & 0,0806 & 3,98 & 0,320 \\
\hline
\end{tabular}




\begin{tabular}{|l|c|l|c|c|}
\hline Atribut & $\begin{array}{c}\text { RATA-RATA } \\
\text { SKOR } \\
\text { KEPENTING } \\
\text { AN (RSP) }\end{array}$ & $\begin{array}{c}\text { WEIGHTIN } \\
\text { G FACTOR } \\
\text { [WF=(RSP/ } \\
\mathbf{5 3 , 0 5} \text { ] }\end{array}$ & $\begin{array}{c}\text { RATA-RATA } \\
\text { SKOR } \\
\text { KEPUASAN } \\
\text { (RSK) }\end{array}$ & $\begin{array}{c}\text { WEIGHTED } \\
\text { SCORE } \\
\text { [WS=(RSK } \\
\text { X WF)] }\end{array}$ \\
\hline $\begin{array}{l}\text { Ukuran } \\
\text { bervariasi }\end{array}$ & 3,71 & 0,0699 & 3,89 & 0,271 \\
\hline $\begin{array}{l}\text { Kemudahan } \\
\text { memperoleh kopi }\end{array}$ & 3,94 & 0,0742 & 3,82 & 0,283 \\
\hline $\begin{array}{l}\text { Bentuk atau desain } \\
\text { kemasan }\end{array}$ & 3,75 & 0,0742 & 3,44 & 0.255 \\
\hline $\begin{array}{l}\text { Jaminan halal dan } \\
\text { sehat }\end{array}$ & 4,39 & 0,0827 & 3,92 & 0,324 \\
\hline Iklan kopi & 3,86 & 0,0727 & 3,31 & 0,240 \\
\hline $\begin{array}{l}\text { Ketersedian } \\
\text { tanggalkadaluarsa } \\
\text { pada produk }\end{array}$ & 4,50 & 0,0848 & 3,95 & 0,334 \\
\hline $\begin{array}{l}\text { Lokasi penjualan } \\
\text { kopi }\end{array}$ & 3,95 & 0,0744 & 3,78 & 0,281 \\
\hline $\begin{array}{l}\text { Daya tahan kopi } \\
\text { untuk disimpan }\end{array}$ & 4,31 & 0,0812 & 3,86 & 0,313 \\
\hline $\begin{array}{l}\text { Kemudahan } \\
\text { dilarutkan }\end{array}$ & 5,34 & 0,0818 & 48,96 & 0,327 \\
\hline $\begin{array}{l}\text { Jumlah } \\
\text { CSI = (WT : 5) x 100\% }\end{array}$ & 1 & & 70,48 \\
\hline
\end{tabular}

Meskipun berada pada rentang kriteria puas, namun nilai indeksnya masih belum mencapai 100 persen (sebesar 0,7048 berada pada rentang 0,66-0,80). Hal ini disebabkan masih terdapat 29,52 persen $(100-70,48=29,52)$ konsumen dari total responden yang belum mampu dipuaskan sepenuhnya oleh produk Kopi Nefo Cap AAA. 


\subsection{Pengujian Loyalitas Pelanggan}

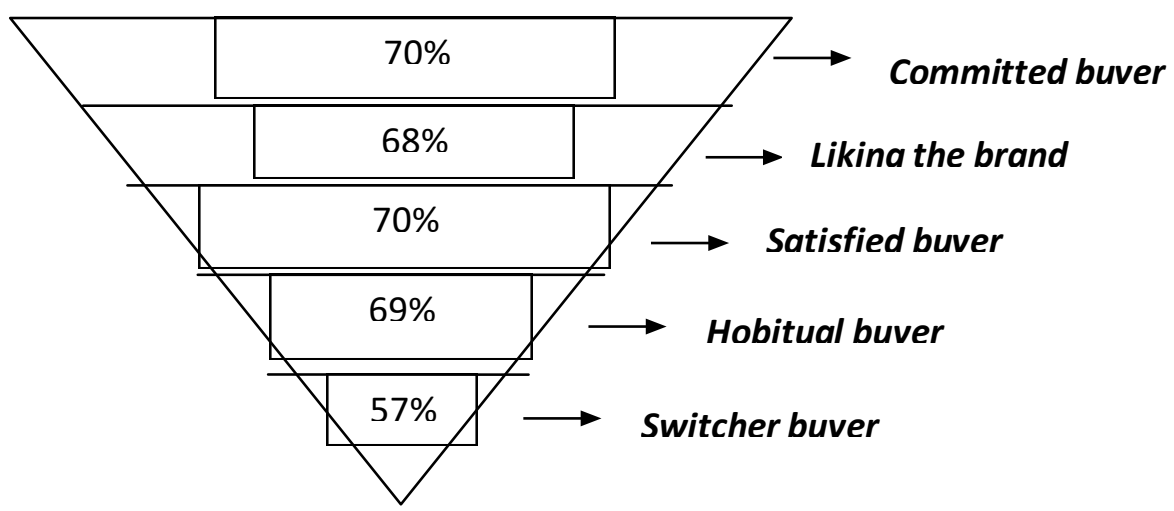

Gambar 2: Primada Loyalitas Konsumen Kopi Nefo Cap AAA

Gambar 2 menunjukan kondisi konsumen Kopi Nefo Cap AAA. Pada tingkat loyalitas merek, responden yang merupakan Switcher sebesar 57 persen, kondisi seperti ini termasuk dalam kategori yang harus diperhatikan karena jumlah Switcher buyer lebih dari 50 persen. Responden yang merupakan hobitual buyer 69 persen, kondisi ini menunjukan bahwa konsumen suka terhadap produk Kopi Nefo Cap AAA. Responden yang merupakan satisfied buyer 70 persen, kondisi ini menunjukan bahwa konsumen Kopi Nefo Cap AAA sudah merasa puas terhadap produk Kopi Nefo Cap AAA. Responden yang merupakan liking the brand 68 persen, kondisi ini menunjukan bahwa Konsumen Kopi Nefo Cap AAA termasuk dalam kategori suka terhadap Kopi Nefo Cap AAA. Responden yang merupakan committed buyer sebesar 70 persen, kondisi loyalitas seperti ini termasuk dalam kategori baik dikarenakan jumlah committed buyer lebih dari 50 persen.

\section{Kesimpulan dan Saran}

\subsection{Kesimpulan}

1. Tingkat kepuasan konsumen terhadap kinerja yang diberikan produk Kopi Nefo Cap AAA berada pada tingkat PUAS yaitu sebesar 70,48 persen, jadi harapan atau tingkat kepentingan konsumen telah dipenuhi oleh Kopi Nefo Cap AAA sebesar 70,48 persen. Atribut yang telah berhasil dilaksanakan oleh Kopi Nefo Cap AAA ialah atribut kemudahan dilarutkan, kesehatan dan kebersihan, ketersediaan tanggal kadaluarsa, jaminan halal, daya tahan, rasa, atribut-atribut ini harus dipertahankan olehCV.Nefo.

2. Gambar piramida loyalitas Kopi Nefo Cap AAA secara umum dapat dikatakan sudah cukup baik. Pada level Switcher/Price Buyer memiliki jumlah persentase cukup besar yaitu 57 persen. Hal ini dapat menyebabkan berkurangnya jumlah penjualan dimasa yang akan datang disebabkan konsumen pada level ini kemungkinan akan berpindah pada merek kopi bubuk yang lain jika ada produsen 
yang menjual kopi bubuk yang lebih murah dengan kualitas yang sama dengan merek Kopi Nefo CapAAA.

\subsection{Saran}

1. Konsumen Kopi Nefo Cap AAA sudah merasa puas terhadap Kopi Nefo Cap AAA hal ini harus tetap dipertahankan oleh CV. Nefo, salah satunya seperti atribut kemudahan dilarutkan, kesehatan dankebersihan, ketersedian tanggal kadaluarsa, jaminan halal, serta daya tahan produk. Dengan menjaga dari atribut-atribut tersebut pada produk Kopi Nefo Cap AAA kemungkinan pelanggan pindah ke produk lain menjadi kecil. Atribut yang harus diperhatikan oleh CV.Nefo ialah atribut ukuran berat bervariasi, kemudahan memperoleh, dan lokasi penjualan atribut ini merupakan atribut yang harusdiperhatikan.

2. Konsumen Kopi Nefo Cap AAA masih rentan terhadap harga, dari data Switcher/ Price buyer tingkat kesensitifan konsumen Kopi Nefo Cap AAA terhadap harga masih besar lebih dari 50 persen, hal ini menjadi perhatian besar untuk CV. Nefo supaya lebih memperhatikan harga Kopi Nefo Cap AAA. Untuk Hobitual Buyer, Satisfied Buyer, Liking The Brand, dan Committed Buyer harus dipertahankan.

\section{Referensi}

Awan. (2014). Impact of Customer sttisfaction on Brand Loyalty-an Empirical Analysis of Home Appliances in Pakistan.Journal Customer Loyalty.

Curtis, dkk. (2011). Customer Loyalty, Repurchase and Statisfaction : a Metaanalytical Review.Customer Loyalty.

ICO. (2009). abaout coffea.Dipetik january 5, 2017, dari http://www.ICO.org Dusrianto, D dkk. 2004. Strategi Menaklukan Pasar Melalui Riset Ekuitas dan Perilaku Merek. Gramedia Pustaka Utama, Jakarta

Huan, T. C., \& Beaman, J. (2005).Importance performance analysis the need to bridge solitudes for its effective use.jurnal marketing , 77-79.

Hendrayani. (2008). Analisis Tingkat Kepuasan dan Loyalitas konsumen Terhadap Produk Gulaku di Kota Bogor (studi kasus di Giant Botani Square dan Ramayana BTM).Analisis kepuasan.

Kelena. (2007). Tingkat Kepuasan dan Loyalitas Pelanggan Restoran Bandar Djakarta di Jakarta Utara.Tingkat Kepuasan dan Loyalitas .

Mico. (2016). Kopi “KOPI KORINTJI” masuk 10 besar kopi terbaik Indonesia. Dipetik januari 3, 2017, dari http://www.Korintji.com

Suliyanto. (2005). Analisis Data dalam Aplikasi Pemasaran.Ghalia Indonesia. Ciawi Bogor. 